Cuadernos de Filología Italiana

ISSN: 1133-9527

https://dx.doi.org/10.5209/cfit.62037

\title{
Tormento y tormenta de amor: dos reescrituras de un soneto de Petrarca
}

\author{
Marco Federici ${ }^{1}$
}

Recibido: 19 de octubre de 2018 / Modificado: 07 de enero de 2019 / Aceptado: 14 de febrero de 2019

Resumen. El artículo analiza dos versiones del soneto CXXXII de Petrarca, las de Pedro de Cartagena y Joan Boscán, de época anterior y contemporánea a la nueva orientación petrarquista respectivamente. Además del análisis con respecto al soneto original italiano, el discurso se detiene en el uso del verbo tratar en posición de rima, cuyo empleo y etomología parecen sugerir unas referencias a una tradición literaria distinta de la amorosa. El análisis demuestra que ambos poetas castellanos se concentran en un aspecto del soneto original, dejando al lado la imagen metafórica del navigium amoris, o para mejor decir, referiéndose a ella de manera mucho más alusiva.

Palabras clave: Petrarca, Canzoniere, Pedro de Cartagena, Joan Boscán, traducción.

\section{[en] Torment and storm of love: Two rewrites of a Petrarch's sonnet}

\begin{abstract}
The article analyzes two versions of Petrarch's CXXXII sonnet, by Pedro de Cartagena and Joan Boscán, in the earlier and contemporary period of the new Petrarchan orientation respectively. Besides the comparison with the original Italian sonnet, the argument is focused on the use of the verb tratar in position of rhyme. The use and etomology of this verb seem to suggest references to a literary tradition different from the amorous one. The analysis shows that both Castilian poets are more focused on one aspect of the original sonnet, and they leave aside the metaphorical image of the navigium amoris, or to say it better, they use this image in a much more allusive way.
\end{abstract}

Keywords: Petrarch, the Canzoniere, Pedro de Cartagena, Joan Boscán, translation.

Sumario: 1. Introducción 1.1. Petrarquismo mediato: las traducciones (Trionfi y Canzoniere) 1.2. Recepción de Rvf CXXXII 2. Si amor no es quien me trata de Pedro de Cartagena (siglo XV) 3. Bueno es amar, pues ¿cómo daña tanto? de Joan Boscán (siglo XVI) 4. La renuncia a escaparse de las cuitas de Amor 5. Observaciones conclusivas.

Cómo citar: Federici, Marco (2019): «Tormento y tormenta de amor: dos reescrituras de un soneto de Petrarca», Cuadernos de Filología Italiana, 26, pp. 143-166.

1 Sapienza Università di Roma. Dipartimento di Studi Europei, Americani e Interculturali, P.le Aldo Moro 5, I-00159 - Roma.

albricia@libero.it 


\section{Introducción}

\subsection{Petrarquismo mediato: las traducciones (Trionfi y Canzoniere)}

El fenómeno petrarquista en España empieza por la lectura y la imitatio (directa o indirecta) de las obras del poeta de Arezzo -en particular los Trionfi y el Canzonierecuyas huellas aparecen ya en los autores de la Edad Media española y se remontan a una época anterior a la de las traducciones "oficiales", que se realizan en el período renacentista ${ }^{2}$. Se trata de unas deudas petrarquescas en los poetas de cancionero que, en palabras de Francisco Rico (1987: 230), son difíciles de percibir «perché le tecniche e i modi cancioneriles trasformano molto profondamente i materiali petrarcheschi dissolvendone le immagini in astrazioni, distillandone i concetti, mutando il tempo del pensiero nel cambiare il ritmo alla dizione».

Es bien sabido que la traducción al castellano de los Trionfi fue anterior a la de los Rerum vulgarium fragmenta (Rvf), aunque en ambos casos la difusión, parcial y completa, de estas obras en lengua española llegó después de una honda penetración de temas y del estilo petrarquistas en los años a caballo de los siglos XV y XVI ${ }^{3}$. A diferencia de los Trionfi, la transmisión de los poemas del Canzoniere en castellano empieza por una serie de imitaciones y traducciones de sonetos aislados, cuyas primeras apariciones se identifican a partir del siglo $\mathrm{XV}^{4}$; esta actividad de refundición lingüística de los fragmenta floreció en el XVI, cuando, por ejemplo, once sonetos de Petrarca aparecieron en castellano de la pluma de un traductor anónimo en el Cancionero general de obras nuevas (1554), «the earliest anthology published in Spain containing verses composed in both the traditional and Italian measures» (Crawford 1916: 328), verdadera confluencia entre la lírica tradicional española y el petrarquismo, y cuya edición coincidió con la impresión de los Triumphos de Hoces $^{5}$. Estamos en el auge del petrarquismo español, cuando ya se había publicado la carta de Boscán a la duquesa de Soma (1543), donde se trata del encuentro entre el barcelonés y Navagero (1526) y que apareció póstuma en las Obras de Boscán y algunas de Garcilaso (1547 y 1553).

Para llegar a las traducciones del Canzoniere hay que esperar los últimos cuarenta años del XVI, y precisamente el año 1567, cuando en Venecia ve la luz el impreso De los Sonetos, Canciones, Mandriales y Sextinas del gran poeta y orador Francesco Petrarca del judío portugués Salomón Usque ${ }^{6}$; en aquellos años, Henrique Garcés debía estar a punto de terminar su propia traducción, Los sonetos y cancio-

2 Nos limitamos a citar a Lapesa (1962 [1967]), Rico (1978), Manero Sorolla (1987) y (1990). Para una bibliografía pormenorizada, véase Valero Moreno (2015). Los orígenes de los estudios sobre Petrarca en la península ibérica se exploran en Valero Moreno (2015b).

3 La traducción de los Trionfi la realizó primero Antonio de Obregón (1512), en octosílabos, y luego Hernando de Hoces (1554), en endecasílabos. Añádase la traducción en versos de arte menor de únicamente un triunfo (el Triumphus Cupidinis) por Álvar Gómez de Guadalajara, realizada alrededor de 1510, que se transmite en cancioneros y en apéndice a las ediciones de La Diana de Montemayor, a partir de 1561.

4 La primera taducción de un soneto de Petrarca al castellano es la de Rvf CXLVIII (No Tesin, Po, Varo, Arno, Adige et Tebro), conservada en las hojas finales del ms. 10186 de la Biblioteca Nacional de España (f. 195-198). Véase al respecto Rubio Tovar (2005).

5 Sobre el Cancionero general de obras nuevas se remite esencialmente a la edición de Clavería (Nájera 1993) y a los estudios de Montero (2005) y Caravaggi (2014).

6 Véanse la edición de Canals Piñas (2009) y sus anteriores trabajos: Canal Piñas (2007), (2005) y (1994). Véase además Manero Sorolla (1989). 
nes del poeta Francisco Petrarcha (Madrid, 1591), en la que tenemos todos los sonetos italianos a excepción de los babiloneses (Rvf CXIV, CXXXVI, CXXXVII, CXXXVIII) que el español no encontró en su texto de referencia ${ }^{7}$. Por último, Las rimas inéditas de Trenado de Ayllón (ms. Egerton 2062 de la British Library) están fechadas en $1595^{8}$. Amén de estas traducciones de buena parte de los poemas del Canzoniere, en el siglo XVI varios e importantes autores siguieron imitando y traduciendo sonetos de Petrarca de forma aislada, y los incluyeron en sus propias obras $^{9}$. Estamos frente a una importante presencia de refundiciones de poemas petrarquescos, a una fecunda actividad traductora que refleja una corriente cultural y literaria de la época, tanto como en el caso de las obras de pura creación (Rubio Tovar 1997: 203). Además, las versiones del siglo XVI de los $R v f$ representan -en palabras de Furio Brugnolo (2006: 289-290) - un pasaje fundamental en la historia de la traducción poética: son el testimonio de un claro cambio de ruta, por el que los traductores apuntan ahora sea al respeto del texto original y a la correcta transmisión del mensaje poético, sea a la transposición de sus específicas peculiaridades formales y estilísticas, para que la traducción sea un equivalente del original que pasa de una lengua a otra.

\subsection{Recepción de $R v f$ CXXXII}

El propósito de este artículo es analizar dos adaptaciones castellanas del afortunado soneto S'amor non è, che dunque è quel ch'io sento? de Petrarca (RvfCXXXII), que no encajan en el cambio metodológico de la traducción evidenciado por Brugnolo, aunque se muestren mucho más cercanas a la versión original de lo que a primera vista parece, y comparten elecciones temáticas y léxicas. El soneto italiano examinado es cronológicamente el segundo poema del Canzoniere que se tradujo en la península ibérica y el primero de los fragmenta vertido al castellano en el siglo XVI, época de extrema importancia en la formación de la conciencia lírica en la lengua de Garcilaso a partir del modelo petrarquista. Amén de esto, y en consideración de los datos a nuestro alcance, $R v f$ CXXXII sería el soneto con más versiones al castellano entre los siglos XV y XVIII, versiones que a menudo aparecen fuera de un contexto lírico o bien incluidas en la parcial transposición del Canzoniere de Usque y en la completa de Garcés, pero no en las Rimas de Trenado de Ayllón ${ }^{10}$. Por último, este soneto es el único cuyas traducciones e imitaciones se atestiguan en cada uno de los cuatro siglos en los que se registra su difusión; un éxito parecido al de RvfCCLXXII, aunque de este último no se haya encontrado -hasta donde se nos alcanza- una versión en el siglo XV español.

El soneto CXXXII forma parte de la sección de las rimas In vita di Madonna Laura. Leamos el texto:

7 Bartomeu Masiá (2007). Sobre la traducción de Garcés, véanse Garribba (2013); Brugnolo y Garribba (2006); Garribba (2005); Garribba (2003a, 2003b).

8 Sobre la traducción de Francisco Trenado de Ayllón, véanse Canals Piñas (2007 a/b); Krebs Bermúdez (1995).

9 Nos limitaremos a nombrar a Hernando Díaz (1516), Alvar Gómez de Castro (1560-1570 c.), Diego de Fuentes (1563), Damasio de Frías y Balboa (1570-1580 c.), Gregorio Silvestre (1582) y Lope de Vega (1593). Para más referencias se remite a las fichas del PROYECTO BOSCÁN: Catálogo de las traducciones españolas de obras italianas (hasta 1939). <http://www.ub.edu/boscan> [consulta: 27 de septiembre de 2018].

10 Una primera muestra de las muchas versiones de $R v f$ CXXXII se ha ofrecido en Federici (2018). 
S'amor non è, che dunque è quel ch'io sento?

Ma s'egli è amor, perdio, che cosa et quale?

Se bona, onde l'effecto aspro mortale?

Se ria, onde sí dolce ogni tormento?

S'a mia voglia ardo, onde 'l pianto e lamento?

S'a mal mio grado, il lamentar che vale?

$\mathrm{O}$ viva morte, o dilectoso male,

come puoi tanto in me, s'io no 'l consento?

Et s'io 'l consento, a gran torto mi doglio.

Fra sí contrari vènti in frale barca

mi trovo in alto mar senza governo,

sí lieve di saver, d'error sí carca

ch'i' medesmo non so quel ch'io mi voglio,

et tremo a mezza state, ardendo il verno (Petrarca 2004: 408) ${ }^{11}$.

Cabe recordar que Se amor non è, che dunque è quel ch 'io sento? debía «incontrare tanto favore fino al sec. XVIII», porque poseía, junto con otros sonetos del poeta italiano, «una tendenza agli artifici della vecchia lirica»y «nulla di tipicamente petrarchesco» (Praz 1935). La misma apreciación hacia una poesía arcaica que, posiblemente, llevó al anónimo traductor castellano del Decameron a traducir a su idioma únicamente la balada de Mico da Siena $(X, 7)$-que aparece a partir de la princeps de 1496- cuyos rasgos estilísticos arcaizantes ya se advertían en la época de Boccaccio ${ }^{12}$. De todas formas, para demonstrar el éxito europeo de $R v f \mathrm{CXXXII}$, es suficiente recordar las varias transposiciones en distintas lenguas de un soneto que, junto con $R v f$ CXXXIV, se configura «casi como una prueba de fuego en el "oficio" -también en sentido artesanal- de los poetas petrarquistas» (Brugnolo / Garribba 2006: 291): lo tradujo al latín Coluccio Salutati (Si fors non sit amor, igitur quid sentio? vel si) -que también vertió el afín Pace non trovo, et non ò da far guerra (Rvf CXXXIV) - al inglés Geoffey Chaucer (If no love is, o God, what fele I so?) -y fue el único soneto de Petrarca traducido en Inglaterra (Melchionda 19775); en Francia, el poema se encuentra entre los incluidos en Les auvres poëtiques de Jacques Peletier du Mans (París, 1547; cf. Tucci 2016; Balmas 1975), y en Alemania lo tradujo Martin Opitz (Cases 1975).

En España es, en cambio, a partir del verso ¿Si no ès amor, donchs, açò què serà? del valenciano Jordi de Sant Jordi (Cançó d'opòsits) que encontramos -junto con otras referencias- un calco patente de $S$ 'amor non è, che dunque è quel ch'io sento? y de otros versos procedentes del Canzoniere ya en la Edad Media. Dicha analogía la señaló Gaspar Escolano en su Historia de Valencia (libro I, cap. XIV, p. 90): el historiador valenciano -cuyo interés hacia la lengua y la literatura medieval es de sobra conocido (Romà Herèdia 2014) - afirmaba que Petrarca había plagiado este y otros versos de un célebre «Mossen Jordi», nacido en su opinión cien años antes que el poeta toscano. Para corroborar su teoría, Escolano ofrecía los siguientes versos en comparación:

Se cita de la ed. de Ugo Dotti (Petrarca 2004)

Sobre esta traducción véase Federici (2016). 
El Petrarca dice:

Pace non trovo e non he do far guerra, e volo sopra il cielo, e ghiaccio in terra; e nulla stringo e tutto il mundo abbraccio.

Et ho in odio me esteso e amo altrui:

Si amor non he, chè dunque è quel che sento?

\section{Mosèn Jordi dijo:}

E non he pau, e no tinch qui n guerreig;

Vol sobre 1 cel e non moví de terra;

e no estrench res e tot lo món abràs;

Oi he de mi e vull altri gran bé:

¿Si no és amor, donchs, açò què serà?

Los ejemplos ofrecidos por Escolano remiten esencialmente a Rvf CXXXIV (vv. $1,3,4,11)$ y a $R v f$ CXXXII (v. 1), cuyas afinidades retóricas, fundadas en la antítesis, bien encajaban en el canon de los poetas ibéricos medievales. Las afirmaciones del historiador, que «tractava de potenciar la tradició valenciana i ibèrica per damunt de la italiana» (Romà Herèdia 2014: 66), debieron parecer muy bien fundadas, por estar acompañadas de puntuales referencias a soporte de su teoría.

El caso sobre la procedencia valenciana de los versos del poeta de Arezzo también llamó la atención de Ugo Foscolo, quien en sus Saggi sopra il Petrarca vaciló frente a las afirmaciones de Escolano ${ }^{13}$. En realidad, como aclaró entre otros Ugo Dotti, «il Petrarca era l'imitato, non l'imitatore», porque Mossen Jordi de Sant Jordi murió después del autor de los fragmenta y «diffuse il petrarchismo alla corte di Alfonso il Magnanimo e del principe Carles de Viana» (Petrarca 2003: 33).

El de Escolano no fue el único caso en el que se defendía la tradición poética española frente a la italiana, y la dependencia de esta última con respecto a la otra: en pleno Renacimiento, Petrarca fue tachado de plagio también en las Obras del excelentísimo poeta Ausias March (1579), cuya traducción al castellano realizó Jorge de Montemayor. En las páginas preliminares, del parecer de López de Hoyos aflora cierto orgullo nacional, parecido al que supuestamente tuvo Gaspar Escolano:

Por mandatdo de Vuestra Alteza he visto este libro de poesía del famoso Poeta Ausiàs March, el qual es poeta español y escrivió en lengua lemosina, que es lengua entre catalana y algo de gallega y valenciana. Está traduzido en castellano por Jorge de Montemayor. En lo que toca a sus conceptos, es tan subido que los de muy delicado juycio creen que Petrarca tomó muchos de los muy delicados que tiene deste autor. Es digno de ser impresso. En todo lo demás va muy correcto y digno de que sus buenos conceptos se vean y sepan, pues son de hombre de nuestra España, que es valenciano (f. 2 r) $)^{14}$.

13 Foscolo (1824: 72): «Ma il fatto sta, che Messen o Mossen Jordi, o Messer Giorgio era un gentiluomo di Valenza, che fioriva verso la metà del secolo XIII, il che si comprova dall'essere stato egli cortigiano di re Giacomo il Conquistatore, e coll'autorità non solo di Gasparo Scuolano, ma del Quadrio (DELLA STORIA E DELLA RAGIONE D'OGNI POESIA. Vol II. fac. 124), e de' dizionari storici, i quali dicono concordemente, che fiorì circa il 1250; e però anteriore al Petrarca nato del 1304».

14 Se cita del ejemplar de Madrid (Francisco Sánchez, 1579) conservado en la Biblioteca de Catalunya, signatura Bon. 10-I-25. Se han regulado la puntuación, las mayúsculas y la acentuación del texto. Las cursivas son mías. 


\section{Si amor no es quien me trata de Pedro de Cartagena (siglo XV)}

La primera reescritura de $R v f$ CXXXII en lengua castellana se encuentra en la versión cuatrocentista del converso Pedro de Cartagena, y su datación aún es incierta: seguramente fue compuesta antes de 1486, fecha de la muerte del poeta cancioneril, tuvo una primera circulación manuscrita y luego fue incluida en el Cancionero General de Hernando del Castillo (1511). Esta reescritura del soneto de Petrarca representa un claro ejemplo del hecho de que el escritor español «conoce y aprovecha la poesía italiana» (Alonso 2001: 145). Cartagena vertió con bastante libertad al castellano algunas partes del soneto original, que más parecen servir de inspiración para componer unas coplas parecidas e inspiradas en los versos del poeta italiano:

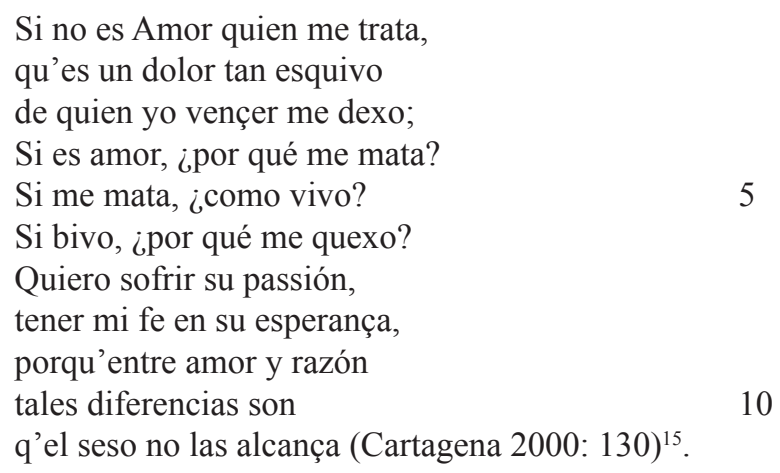

El poeta cancioneril no se limita a la libre transposición en su lengua madre, sino que desarrolla ulteriormente su propia composición a partir del v. 7, y se aleja -al parecer- del modelo italiano. En primer lugar, destaca el uso del octosílabo, medida tradicional española, y la repartición en dos coplas: una sextina y una quintilla, en las que prevalece el verso paroxítono a excepción de en los vv. 7,9. La primera copla se compone de seis versos de arte menor, con esquema $a b c a b c$, diferente con respecto a los tercetos originales $(C D E D C E)$, aunque se mantenga la construcción fundada en el uso de tres rimas. La segunda copla se compone en cambio de dos rimas, con esquema abaab.

De esta versión cancioneril del siglo XV, Álvaro Alonso (2005: 236) reconoce los tres primeros versos del soneto original; Whetnall (2006: 99-101), en cambio, identifica también una equivalencia en la parte final del v. 6 de ambos poemas («Il lamentar che vale?»vs «por qué me quexo?») y las repeticiones de los sintagmas que siguen: «S'amor non è» (v. 1) $\rightarrow$ «Si no es Amor» (v. 1); «s'egli è amor» (v. 2) $\rightarrow$ «Si es amor» (v. 4); «onde l'effecto aspro mortale» (v. 3) $\rightarrow$ «por qué me mata?» (v. 4). Añádase que el v. 4 («Si es amor, ¿por qué me mata?») se construye de la fusión de la parte inicial del v. 2 («Ma s'egli è amor») y de la final del v. 3 («onde l'effecto aspro mortale?») italianos - como ya había notado Álvaro Alonso (2001: 146)-y que se mantiene la anáfora de la conjunción hipotética $s e \rightarrow s i$. Amén de esto, el cierre del v. 2 del soneto («perdio, che cosa et quale?») solo aparentemente parece omitirse:

15 El texto de Rodado Ruiz presenta una variante («como vivo», v. 5) con respecto a las transcripciones («como que vivo», v. 5) de Alonso (2005: 236) y Whetnall (2006: 99) y a la ed. facsímil de 1958 (Madrid, RAE, fol. lxxxviii). Cabe decir que el segmento con el pronombre relativo que añade una sílaba más al octosílabo. 
mientras Petrarca se pregunta sobre la sustancia y la calidad del sentimiento, Cartagena lo define negativamente como «un dolor tan esquivo» (v. 2), por el que el poeta se deja dominar, y contesta de manera explícita a la pregunta de apertura del poeta toscano «che dunque è quel ch'io sento?» (v. 1), en la que se sobrentiende un sentimiento de dolor y de fuerte sufrimiento interior.

A partir de estas consideraciones, sería preciso sugerir otra interpretación de los primeros tres versos de Cartagena, alternativa a la ofrecida en la edición de Rodado Ruiz (Cartagena 2000: 130) y que mantendría una conexión con las preguntas iniciales el soneto italiano:

Si no es Amor quien me trata ¿qué es un dolor tan esquivo?

¿De quién yo vençer me dexo?

vínculo que no se le había escapado a Dutton (1990-1991: V, 233) al editar el texto del poema:

Si no es Amor quien me trata ques un dolor tan esquivo ¿de quién yo vençer me dexo?

y que también percibió Álvaro Alonso (2005: 236):

Si no es Amor quien me trata

¿ques un dolor tan esquivo

de quien yo vençer me dexo?

A propósito de las diferencias con respecto al original, Whetnall (2006: 100) identifica la pérdida de las antítesis «dolce tormento» (v. 4), «viva morte» (v. 7) y «dilectoso male» (v. 7), y la obtención de un efecto equivalente en la secuencia «ipor qué me mata? / si me mata» (vv. 4-5) y «¿cómo que bivo? / si bivo, ¿por qué me quexo?» (vv. 5-6), que recupera la misma figura retórica del segundo cuarteto («lamento/ [...] lamentar», «s'io nol consento / Et s'io '1 consento»). Sin embargo, el poeta español conserva la figura retórica de oposición en la quintilla, donde la pareja «amor y razón» (v. 9) constituye un contraste sucesivamente remarcado por el término en rima «passión» (v. 7).

La enunciación de estados de ánimo opuestos es el tema que también caracteriza los tercetos italianos, donde Petrarca compara al enamorado con una «frale barca» (v. 10) en poder de los «contrari vènti» (v. 10) e «in alto mar senza governo» (v. 11). Aun en la construcción de esta metáfora abundan las antítesis: «lieve»vs «carca» (v. 12), «saver»vs «error» (v. 12), «tremo»vs «ardendo» (v. 14), «state»vs «verno» (v. 14). El tema de la tempestad es uno de los mayores tópicos del Canzoniere, y una bellísima ilustración de Francesco di Antonio del Chierico lo reproduce en apertura del ms. it. 548 de la Bibliothèque nationale de France. El tópico procede de la tradición clásica del navigium amoris, un conjunto temático ampliamente atestiguado en la literatura de época griega -en la que también adquiría connotaciones sexuales-y romana, donde la navegación se asocia a la relación amorosa (Laguna Mariscal 2011: 424-425). En particular, en el tema de la tormenta de amor entran «las desgracias, 
contratiempos, contrariedades y cuitas inherentes al amor» que pueden compararse a una «marejada propia de una tempestad», y que en algunos casos funciona de «correlato de los sentimientos de incertidumbre o duda del amante» (Laguna Mariscal 2011: 425-426).

En las coplas de Cartagena no aparece el tema de la embarcación en poder del mar en tormenta a causa de los vientos contrarios, metáfora que de los fragmenta pasa a la poesía española ya en el siglo XV, en particular en el repertorio cancioneril, y que el Marqués de Santillana emplea en su Carta a una dama ${ }^{16}$.

Qual sin patrón el navío,

soy, después que no vos veo,

vida mía y mi deseo,

cuyo só más que no mío (vv. 21-24).

Sin embargo, la presencia del lexema «razón» (v. 9) podría de alguna forma proceder de la imagen del navío a merced de las olas, si se considera la falta de un «governo» (el timón) como privación de la guía de la razón. En efecto, la asociación no parece casual ni baladí, si consideramos el corpus de las poesías de Cartagena en el Cancionero general:

El primer poema que figura en el Cancionero General [...] se inicia con una comparación entre el hombre y un navegante, y una alegoría con el mar de la vida como eje [...] Inocentes y, al tiempo, razonables ideas como las expuestas en los versos 6-9 con la imagen marina de fortuna (tormenta en el mar) frente a bonanza (tiempo tranquilo) [...] La transición hacia temas de carácter menos particular se establece mediante el recuerdo del libre albedrío y la necesidad de asumir la responsabilidad de los propios actos [...] A partir de esta idea se hilvanan una serie de motivos con el fin de mostrar plásticamente la oposición y lucha de los sentidos contra la razón; la libertad es la fusta (barca), la razón el gobernalle (timón), la sensualidad está sujeta a las riendas de la razón, el fuego de las pasiones se combate con el conocimiento de los errores (Cartagena 2000: 53).

En el largo poema de apertura, del que citaremos algunos fragmentos de interés, la metáfora marina no se funda en el binomio presencia vs ausencia-como por ejemplo en El collar de la paloma de Ibn Hazm - sino en el significado de las adversidades (la tempestad) que socavan la tranquilidad del hombre (la bonanza) ${ }^{17}$ :

Si el navegante mirasse

la fortuna que passó,

muy diffícil hallo yo

qu'éste tal más navegasse;

16 Sobre el tema de la tormenta y sobre su presencia en los autores españoles del Siglo de Oro, véase Sarmati (2009). Sobre el motivo de la nave como metáfora del sentimiento amoroso véase también Cortijo Ocaña (2007).

17 Ibn Hazm (2017: 30): «Si me veo forzado a irme de su lado, / no paro de mirar atrás y camino como una bestia herida; / pero, aunque mi cuerpo se distancie, mis ojos quedan fijos en ella, / como los del náufrago que, desde las olas, contemplan la orilla. / Si pienso que estoy lejos de ella, siento que me ahogo / como el que bosteza entre la polvareda y la solana». 
porque, sin dubda ninguna,

es notorio desconcierto

al que ya escapó de una

engolfarse con fortuna

podiendo tomar buen puerto (Cartagena 2000: 76).

La copla se concentra en la resistencia del navegante a volver a la travesía si mirara hacia atrás, es decir, si recordara las tempestades con las que ya se había enfrentado: un tema que, en relación con el argumento amoroso, y en particular en la comparación entre juventud y senectud, aparece en el diálogo entre Celestina y Melibea (Acto IV) que, como indica Severin, procede directamente de Petrarca (De remediis, II, 83):

Loco es, señora, el caminante que, enojado del trabajo del día, quisiese bolver de comienço la jornada para tornar otra vez âquel lugar. Que todas aquellas cosas cuya possessión no es agradable, más vale posseellas que esperallas, porque más cerca está el fin de ellas quanto más andado del comienço. No ay cosa más dulce ni graciosa al muy cansado quel mesón. Assí que, aunque la moçedad sea alegre, el verdadero viejo no la dessea, porque el que de razón y seso carece, quasi otra cosa no ama sino lo que perdió (Rojas 1998: 157).

El cierre de este primer poema de Cartagena añade a la metáfora la idea de «tomar buen puerto» (v. 9), última etapa del viaje por mar pero también alivio de las inquietudes de Amor, según un tópico clásico, ya presente en el De Amore (I:8) y recurrente en Petrarca.

También el binomio entre la razón y su ausencia, metafóricamente identificados en el timón que gobierna o no la nave, aparece claramente en esta composición:

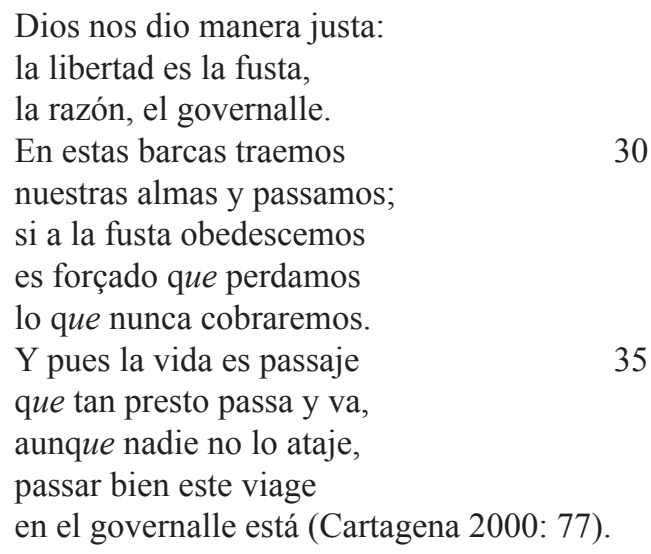

De manera que en las coplas del poeta converso hay varios reenvíos a los tercetos petrarquescos de $R v f$ CXXXII, como la idea de la falta de un gobierno (que hay que evitar, para Cartagena), o del «contrario viento» (v. 57), aunque en este contexto cancioneril los ejes isotópicos de la metáfora expresen una amonestación sobre el libre albedrío: Cartagena se convierte luego en embajador del mensaje moralizante por el que «la sensualidad invita al goce de los placeres terrenales, la razón reco- 
mienda el desprecio de lo mundano» (Cartagena 2000: 77). Tal vez aun sea esta la idea encerrada en los tres versos finales de Si no es Amor quien me trata:

porqu'entre amor y razón

tales diferencias son

q'el seso no las alcança.

La afirmación filosófica conclusiva convierte «la desesperación insistentemente personal de Petrarca, "ch'i medesmo non so quel ch'io mi voglio", en un trillado tópico cancioneril, "quel seso no las alcança"» (Whetnall 2006: 100). El intelecto nunca podrá llegar a percibir las diferencias entre amor y razón, entre instinto y reflexión, entre éxtasis y moderación; se trata de divergencias concretas que trazan una exacta oposición entre las dos capacidades humanas, aunque la razón pueda prevalecer y controlar los impulsos independientes de ella, directa emanación de un instinto natural del hombre. Entonces, el amor afecta a los sentidos, no a la parte racional del alma, ofusca las capacidades de juicio del enamorado, le quita el control de su propia vida y le lleva hasta la muerte. Se trataría de teorías de memoria cavalcantiana, que el poeta florentín explicitaba en el poema Donna me prega ${ }^{18}$. El cierre de Cartagena («q'el seso no las alcança») recuerda en cambio el verso «che lo 'ntelletto mio non vi può gire» (v. 10) de Questa donna ch'andar mi fa penoso, soneto atribuido tanto a Cino da Pistoia como a Dante, en el que se expresa la fuerza de la mirada de la mujer y sus efectos en el enamorado (Pirovano 2012: 730-731).

Estas referencias textuales vincularían el poema de Cartagena con una corriente anterior a la prepetrarquista, recuperada en área ibérica por Ausiàs March:

se l'amore è un accidente, cioè una malattia, come Dante ammette in Vita Nuova XXV («Amore non è per sé sì come sustanzia, ma è uno accidente in sustanzia»), e come ribadisce Guido in Donna me prega (Amore è «un accidente che sovente è fero»), e come ripete pari pari March in Aquelles mans que james perdonaren (v. 191): «Accident és amor y no substança», come si fa ad invocare il consiglio della ragione? Chi lo accetta è già guarito e non ne avverte più il dominio sull'anima! (Pinto 2016: 144-145).

Volviendo al tema de la tormenta de amor en Si no es Amor quien me trata, podría ayudar una interpretación alternativa del lexema en rima «trata» (v. 1), derivado del latín tracto (de traho): procedería de un movimiento espacial y continuo, que podría asociarse al de la barca petrarquesca «senza governo» (v. 11). Por otro lado, ya Aldo Rossellini (1993: 97) notaba que el verbo español traer a menudo se empleaba «con significati somigliantissimi a quelli del latino tractare e dei suoi composti. Traher infatti, vale talvolta dimenare e muovere, come appunto il tractare latino». Por lo dicho, la interpretación del íncipit podría ser: 'Si no es Amor quien me agita', además de 'Si no es Amor quien me gobierna'. Esta segunda opción se atestigua, en el

18 Donato Pirovano (2012: xviii) explica: «Per Guido l'amore è una passione travolgente, smisurata e ottenebrante dell'anima sensitiva, quell'anima che è perfezione dell'individuo. Ben diverso è, invece, il piano della speculazione, quell'intelletto possibile - separato e unico per tutta la specie umana - in cui amore non può nulla. La forza irresistibile dell'amore, però, determina instabilità di giudizio e ottenebra l'amante fino a fargli perdere il controllo di sé. L'amore ha la forza di alienare e di trasformare l'innamorato, e non si placa finché non ottiene da se stesso appagamento: l'unica ricompensa che un amante può aspettarsi è la corrispondenza della donna». 
siglo XVI, en la traducción de Garcés del verso «come '1 sol neve, mi governa Amore» (RvfCXXVII, v. 45) $\rightarrow$ «como a la nieve el Sol, amor me trata» (Garribba 2003b: 72). Aunque en este último caso el verbo parece corresponder simplemente al trattare italiano, la elección de Garcés podría ayudar a confirmar una referencia al tema de la nave en Cartagena: governare es término empleado también en el léxico naval para indicar el uso del timón, sin el que se halla el navegante de $R v f$ CXXXII, por estar en poder de la tormenta de amor que trastorna su alma («mi trovo in alto mar senza governo», v. 11).

Entre las posibles interpretaciones de tratar no se puede excluir la acepción 'maltratar', atestiguada entre las del lexema latín en Plauto (Miles gloriosus, v. 492): «tractatam et ludificatam» ('maltratada y escarnecida'). Si esta hipótesis interpretativa fuese correcta, se trataría de una elección semántica del poeta converso no tan alusiva: en cualquier caso, el verbo tratar en rima indicaría los sufrimientos del enamorado causados por la convivencia de opuestos estados de ánimo, manteniendo también aquella idea de movimiento que figuraba la metáfora marina petrarquesca. Así las cosas, el poema del converso español no volvería a proponer el significante sino el significado de la metáfora, y eliminaría la transposición simbólica de las imágenes, pero aludiendo a ellas a través de la polisemia de tratar. Al mismo tiempo, la elección polisémica mantendría un recurso a la paranomasia tormenta/tormento, típico de la lírica cuatrocentista.

Otro ejemplo del uso de tratar en posición de rima en los poemas de Cartagena se encuentra en los versos finales de la canción Yo soy vos y vos soys yo (vv. 25, 31), dirigida al «Visconde de Altamira seyendo competidores en servicio de una dama»:

Nuestra gloria muerta es:

tal desventura nos tracta

nuestra desdichada suerte

que mirallo y vello es

que la muerte que nos mata

es tardarse nuestra muerte.

Porque tan alto combate,

aunque partido se tracte,

bien vedes vos no nos vale,

pues porqu'el mal nos yguale

rogad vos a Dios c'os mate,

que a mí el alma se me sale (Cartagena 2000: 110). 35

Estos versos parecen confirmar la distinta acepción del término: las dos presencias de tractar (vv. 25, 31) siempre aparecen en rima con matar (vv. 28, 34) lexema que pertenece al campo semántico de la muerte; por esto, a partir de la idea de una variante morfológica del binomio tradicional cancioneril vida $v s$ muerte, en el primer caso «tracta» (v. 25) debería referirse a una condición del yo lírico en vida, es decir, a la «muerte que nos mata» (v. 29); al amor como una muerte continua, como un vivir muriendo, una turbación propia de la condición del enamorado. En cambio, en el segundo caso el verbo en rima «tracte» (v. 31) al subjuntivo mantiene la más típica acepción impersonal que indica el tema sobre el que converge el interés del autor: "Aunque se trate de un combate "convenido" es la dama quien tiene la última palabra y ella sigue diciendo no» (Cartagena 2000: 110). 
Efectivamente, esta peculiar acepción de tratar aparece en Cartagena diferente con respecto, por ejemplo, a Jorge Manrique, que se refiere a la forma con la que Amor trata al enamorado:

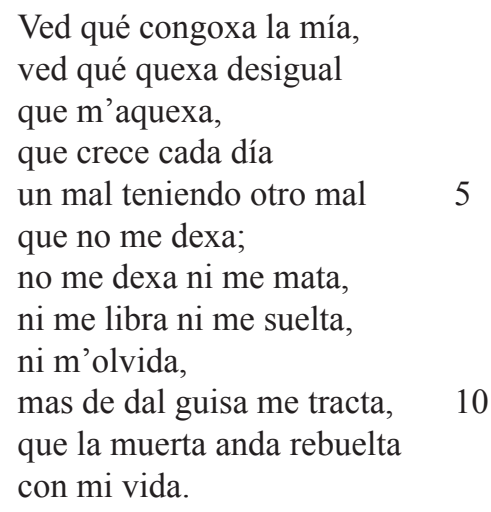

A parte de la analogía en la posición del lexema en final de verso, y también en rima con «mata», el uso del segmento «de tal guisa me tracta» (v. 10) deja poco espacio a malentendidos y ambigüedades semánticas.

También en las Coplas de las calidades de las donas de Mosén Pedro Torellas, el lexema «tracta» (v. 41) -aquí no en posición de rima- no parece tener el mismo valor que se ha hipotetizado en Cartagena:

Por non ser poco estimadas
de quien mucho las estima,
faziendo de honestidad rima,
fingen de mucho guardadas;
mas con quien las tracta en son
de sentir lo que meresçen,
sin detener galardón,
la persona y corazón
abandonan e ofreçen (Gerlo 1994: 333).

Por otra parte, el amor que describe Cartagena es «un dolor tan esquivo» (v. 2), lo que no solo confirmaría la posibilidad de una acepción negativa de tratar, sino también una referencia más al soneto de Petrarca: de hecho, el adjetivo «esquivo» posee entre sus significados el de 'desdeñoso' y 'áspero' (desagradable pero también violento); el lexema tratar recuperaría entonces la percepción implícita de «l'effecto aspro» además de «mortale» (v. 3), en el segmento textual donde Whetnal (2006: 99-100) había reconocido un reenvío al campo semántico de la muerte («effecto [...] mortale» $\rightarrow$ «me mata»).

\section{Bueno es amar, pues ¿cómo daña tanto? de Joan Boscán (siglo XVI)}

Esta peculiaridad en el uso del verbo tratar vuelve a presentarse en Joan Boscán, otro imitador del mismo soneto de Petrarca del siglo XVI. El autor catalán incluyó 
su versión de $R v f \mathrm{CXXXII}$ en las célebres e importantes Obras de Boscán y algunas de Garcilaso (Barcelona, Carles Amorós, 1543):

\section{Soneto LV}

Bueno es amar, pues ¿cómo daña tanto?

Gran gusto es querer bien, ¿por qué entristece?

Placer es desear, ¿cómo aborrece?

Amor es nuestro bien, ¿por qué da llanto?

Da esfuerzo amar, pues ¿cómo causa espanto?

Por el amor el bien del alma crece,

pues, ¿cómo así por él ella padece?

¿Cómo tantos contrarios cubre un manto?

No es el Amor el que dolor nos trae.

La compañía que a su pesar él tiene

también a su pesar nos hiere y mata.

El mal en él de nuestra parte cae.

Él solo en nuestro bando nos sostiene

y nuestra paz continamente trata (Boscán 1999: 266) ${ }^{19}$.

El soneto respeta plenamente el endecasílabo, pero contiene una leve variación en los tercetos $(C D E C D E)$ con respecto a su modelo petrarquesco $(C D E D C E)$ : se trata de un esquema de las dos estancias finales que se atestigua con mayor frecuencia (122) en el Canzoniere (Antonelli 1992: 403). Más que traducir S’amor non è, el poeta catalán compone un soneto que es una imitación parcial del original italiano, y que se funda en los primeros ocho versos dejando al lado -como ya había hecho, al menos en apariencia, Cartagena- el tema de la nave en poder de las olas y de los vientos contrarios. La hipótesis quedaría confirmada por el verso «Cómo tantos contrarios cubre un manto?» (v. 8) -tal vez libre interpretación de «come puoi tanto in me, se 'io nol consento?» (v. 8)-, que cierra los cuartetos e introduce los tercetos, en los que se exponen los temas postulados en las dos estrofas de apertura ${ }^{20}$.

En $R v f$ CXXXII, el adjetivo contrari solo aparece en relación con los vientos que sacuden la embarcación, y forma parte de la metáfora que identifica el yo lírico con una nave en poder de la tempestad marina, en busca de un puerto seguro. Con respecto al léxico que remite al tema de la tormenta, Sarmati (2009: 25) recuerda que

nel Canzoniere gli assi isotopici della navigazione amorosa vanno da una serie massima: pilota, mare, vento, aura, vele, antenne, sarte, stelle, onde, scogli ecc. a una serie minima, con la presenza anche di un solo figurante, come scoglio, porto o con il solo termine tempesta, che evoca l'insieme iconografico complessivo ${ }^{21}$.

\footnotetext{
19 Hemos consultado también la reproducción digital del ejemplar de las Obras conservado en la Biblioteca de Catalunya, Sig. BON.7-III-39.

20 Como también en su versión de Solo et pensoso i più deserti campi (Rvf XXXV), «Al comienzo de la obra, el poeta se acerca al modelo, reconociéndolo en los versos, para luego rechazarlo e iniciar una trayectoria nueva» (Cruz 1998: 43).

21 Sobre la presencia del tema (incluso únicamente a nivel léxico) en Boscán, véase Sarmati (2009: 109-135).
} 
En la versión de Boscán, el sustantivo plural «contrarios» funcionaría pues de $f$ gurante y remitiría de manera disfrazada al tópico de la navegación en la tormenta. De manera que de la lectura de los tercetos italianos se percibe la esencia alegórica del tema de los estados de ánimo opuestos, no la imagen marina del navegante preso de los vientos y en una nave sin gobierno. La metáfora encontraba amplio espacio en otro soneto de Petrarca, es decir, Rvf CLXXXIX (Passa la nave mia colma d'oblio) que, como se sabe, Boscán conoce e imita. En la composición de su cancionero, el poeta español no abandona in toto el tópico del naufragio y del alma atormentada que encuentra paz únicamente al refugiarse en un puerto seguro, a reparo de los sufrimientos de amor y estando el enamorado «seguro de tormenta y de tormento» (Boscán, CXVI, v. 4); como, entre otros, en el soneto En alta mar ronpido 'stá el navio, que según Caravaggi sigue el modelo del citado Passa la nave mia colma d'oblio, aunque, a diferencia de Petrarca, el catalán pone un final feliz (Boscán 1971: 126)22.

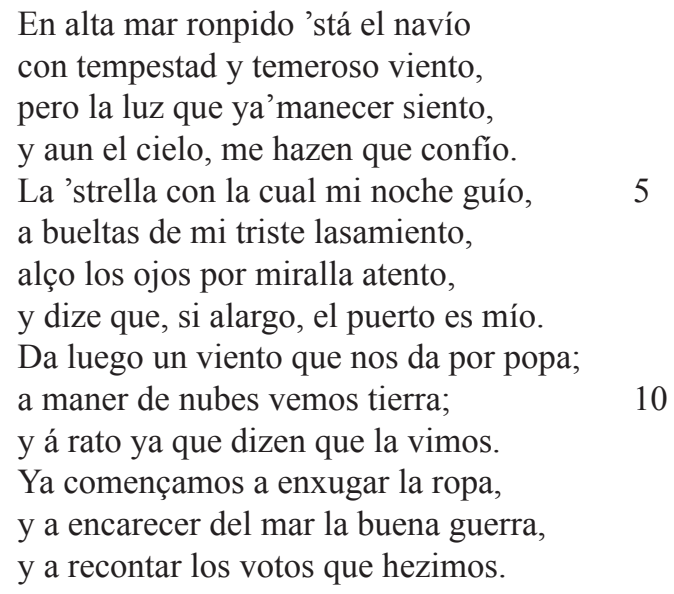

En la falta de adherencia de la traducción de los tercetos de $R v f \mathrm{CXXXII,} \mathrm{el} \mathrm{poeta}$ español cumple con una elección clarísima por la que ya no entiende seguir el soneto original, evitando volver a proponer el tema del naufragio en favor de una mayor concentración en los motivos que desencadenan el conflicto interior del enamorado. Sin embargo, como lo dicho en el caso de Cartagena, la elección en sede de rima del lexema «trata» (de tracto, pero también de traho) podría de manera implícita aludir a la imagen de movimiento que aflora de la metáfora petrarquesca: el último verso «nuestra paz continamente trata» podría entonces sobreentender también que 'nuestra paz continamente atormenta', en relación con los «tantos contrarios» («contrari vènti») retóricamente representados por los juegos de antítesis, pero también por encontrarse el yo lírico «senza governo». De manera que no parecería entonces plausible la correspondencia «governa» $\rightarrow$ «trata», señalada en el comentario a Cartagena y basada en la traducción renacentista de Garcés del verso «come 'l sol neve, mi governa Amore» $\rightarrow$ «como a la nieve el Sol, amor me trata» (RvfCXXVII, v. 45).

Boscán construye su soneto sobre cuatro unidades independientes (Facini 2015: 52) y lo compone a partir de algunos elementos del original: la composición "al itálico modo" sigue un modus operandi por el que el poeta elige los elementos que

22 Para un análisis del tema de la navegación de amor en Boscán, véase Sarmati (2005). 
juzga más apropiados en su adaptación. El soneto se abre con una contraposición entre las opuestas propiedades del sentimiento («Bueno» $v s$ «daña»), en busca de las razones de este doble valor. El íncipit procede del v. 3 de Petrarca («Se bona, onde l'effetto aspro mortale?»); y del mismo verso podría proceder "Amor es nuestro bien» (v. 4). La idea de «l'effetto aspro mortale?» (v. 3), en cambio, podría esconderse en los muchos daños que causa el sentimiento (v. 1). Boscán respeta la estructura del íncipit de Petrarca, mantiene el inciso «dunque» («pues») de los cuartetos, y vuelve a emplearlo como conector en los vv. 6-7, donde el verbo padecer remite al «tormento» italiano (v. 4) ${ }^{23}$. El lexema «aborrece» en rima (v. 3) indica hostilidad y adversión; y podría proceder de «ria» (v. 4), que anuncia la esencia culpable del sentimiento, pero también su calidad de malvado. En este sentido podría explicarse la elección de aborrecer, que da más fuerza a la antítesis con la esencia «dolce» del tormento (v. 4), que vuelve a aparecer en la equivalencia «Placer es desear» (v. 3); se concretaría así un reenvío a dos versos de Es amor una visión de Tapia, donde el amor («doblado dolor») «es un senzillo plazer, / nascido del desear» (vv. 8-9).

El verso «Da esfuerzo amar» (v. 5) subraya la entereza del enamorado, y podría venir de «S'a mi voglia ardo» (v. 5), que indica la voluntad de enfrentar las llamas de amor $^{24}$. En cambio, la pregunta «¿por qué da llanto?» (v. 4) podría proceder de «onde 'l pianto e lamento?» (v. 5), probable punto de partida de «¿por qué entristece?» (v. 2), si entendemos el «lamento» como una queja de débil y triste sonido, mera expresión de dolor.

En los tercetos el poeta catalán contesta a las preguntas anteriores: Boscán establece que «No es el amor el que dolor nos trae» (v. 9), como en el Diálogo entre el amor y un caballero viejo de Rodrigo Cota, donde los ministros de dolor provocan, a pesar de Amor («a su pesar», vv. 10-11), los sufrimientos del enamorado; los mismos ministros que Petrarca, «sconosciuto e pellegrino» en el archipiélago toscano, nombraba para indicar la apremiante llegada de sus preocupaciones amorosas ( $R v f$ LXIX, vv. 12-14).

El cierre del soneto de Boscán se concentra en la idea de la muerte interior, el vivir muriendo tan amado por los poetas de la generación cancioneril española, pero también se detiene en la metáfora del amor que equivale a una guerra, tal vez debido a su perfil de poeta y soldado -como, entre otros, su amigo Garcilaso-, que se encuentra con frecuencia tanto en los fragmenta como entre los poetas españoles de los siglos XV y XVI: valga como ejemplo el caso de la "Escala de Amor" o del "Castillo de Amor" de Jorge Manrique, pero más significativa todavía es la iconografía del siglo XIV del asalto al castillo de amor, muy difundida en Europa (pero de origen francés) y en particular en España (Pérez González 2016).

Es cierto que esta lucha interior «hiere y mata» (v. 11) y atormenta al enamorado («y nuestra paz continuamente trata», v. 14); en este caso, el uso del verbo tratar, además de aludir a una idea de movimiento espacial -como en Cartagena- parece indicar también (a partir de la etimología latina de tracto) el acto de causar aflicción, atormentar al hombre con dolores corporales y no solo en sentido metafórico, también coherente con la interpretación de la antítesis con «paz», y entre «Amor»y

\footnotetext{
La imitación del íncipit del modelo es, según Lefèvre (2013: 88), estrategia dominante en Boscán.

24 El tópico del fuego de amor también está presente en la poesía de Boscán como simple elemento que «riscalda con un tepore primaverile» (Rea 2007: 126).
} 
«dolor» (v. 9), y en estrecha relación con el tema clásico de los tormenta amoris ${ }^{25}$. La procedencia del lema español tratar del latín tracto es cosa cierta, pero entre las acepciones del étimo en el léxico amoroso clásico no se ha encontrado la de 'atormentar' (Forcellini 1771: 760). El uso de tractäre tampoco se atestigua en el repertorio amoroso del tormentum amoris. En cambio, el Diccionario de Autoridades le da a tratar el significado de «Bene, vel male aliquem habere, accipere. Tractare»que se asocia bien a los opuestos efectos del sentimiento-, mientras que Covarrubias y Kossoff (1966: 332) no se acercan a este sentido. Algo parecido parece sugerir el Glosario de voces anotadas en los 100 primeros volúmenes de Clásicos Castalia (Jammes / Mir 1993: 700), que asocia al lema trato la expresión «Trato de cuerda», 'tormento', atestiguada en Lucas Fernández (Farsas, 343), Espinel (Obregón, II, 272), Calderón (Alcalde, 183).

Este significado más feroz del verbo referido a Amor podría proceder de contextos diferentes del amoroso, como el De rerum natura de Lucrecio («malis morsuque ferarum / tractari», III, 888-889); igualmente, el acto de atormentar y provocar un fuerte dolor físico podría esconder una referencia no solo a la idea clásica de un Amor carnifex, sino también a los diabólicos atributos de la iconografía italiana medieval, donde el tradicional niño se representaba con los pies parecidos a las garras de un grifo: «pedes autem gryphis illi ideo apponunt» (Boccaccio, Genealogia Deorum, XI, 4).

Así las cosas, la afirmación «nuestra paz continamente trata» (v. 14) se referiría al tema clásico del miedo de amor, un sentimiento que retrata a Cupido como a un dios amenazador, capaz de alterar la paz interior del hombre y su propia armonía: temores que para los griegos y los romanos también tenían connotaciones eróticas, campo semántico en el que, en cambio, se atestigua el uso de tractāre (Socas 2011: $274)^{26}$. Sin embargo, no podemos excluir por completo la hipótesis de una identificación en el uso del verbo con lo ya dicho en el caso de Cartagena, por el que se aludiría a una paz sacudida, agitada y atormentada; la colocación del verbo en la conclusión del soneto también podría sugerir una correspondencia con respecto a la tormenta marina como metáfora del ánimo trastornado. De todas formas, por su probable polisemia, tratar adquiere una connotación negativa y antitética con respecto a «paz», y otra vez se encuentra, como en Cartagena y Manrique, en rima con «mata», en línea con el legado cancioneril que permanece en la poesía del catalán.

La elección de tal cierre le confiere circularidad al soneto de Boscán: la acepción de tratar relacionada a una idea de Amor carnifex es de hecho coherente con la idea de dañar tanto que abre el soneto. Sin embargo, las oposiciones entre elementos positivos y negativos («bueno» vs «daña») se desvanecerían en favor de la idea de un amor absolutamente cruel.

\section{La renuncia a escaparse de las cuitas de Amor}

La actitud sumisa ante un amor que equivale a un sufrimiento interior por el que el poeta se deja arrollar («de quien yo vençer me dexo», v. 3) no parece en Cartagena tan alejada de lo expresado por Petrarca («a mia voglia ardo», v. 5) en relación con

\footnotetext{
25 El verbo tratar se encuentra, pero con acepción diferente, también en la Elegía a Boscán de Garcilaso: «El fuego, que el amor tenía encendido / de tal suerte lo deja, que lo trata» (vv. 66-67).

26 Sobre las acepciones de tractāre en relación con el autoerotismo véase Matos Fernández (2011: 266).
} 
la voluntad de abandonarse al fuego de amor. Se trata de una conducta pasiva del yo lírico, que en el poema español se remacha por la afirmación «quiero sofrir su pasión» (v. 7), al tiempo opuesta y predominante respecto a la idea antitética del poeta de Arezzo, patente en «S'a mal mio grado» (v. 6), que Cartagena no toma en consideración. Esta actitud del español, deseoso de sufrir las penas de amor y de no dejar que la razón prevalezca, parece revelar la voluntad de rendirse al amor terrenal, contraria a lo expresado por Petrarca, quien por el contrario buscaba el escape de esta dimensión carnal en la intención de abandonarla, para llegar a los sucesivos y superiores niveles del amor platónico.

La voluntad de quedarse el poeta en su estado de sufrimiento aparece opuesta a lo dicho por el mismo poeta toscano, en un soneto en el que el italiano expresaba el temor por lo que más deseaba, es decir, el encuentro con Laura:

Io temo sì de' begli occhi l'assalto ne' quali Amore e la mia morte alberga, ch'i' fuggo lor come fanciul la verga; e gran tempo è ch'io presi 'l primier salto (Rvf XXXIX, vv. 1-4).

Igualmente, la idea de escaparse se repite en «Fuggendo la prigione ov'Amor m'ebbe» (Rvf LXXXIX, v. 1), «Fuggendo spera i suoi dolor finire» (Rvf CLII, v. 12) como también en el bembiano «ché non si vince Amor se non fuggendo» (Soneto LXVIII, v. 14). Sin embargo, la elección de Cartagena parece seguir la idea de que el remedio al amor no se encuentre en alejarse del enamorado -como en Propercio: «quantum oculis animo tam procol ibit amor» (Elegie, III, 21)- ni en su ausencia que, por el contrario pero de manera coherente con la tradición lírica española, aumenta el dolor, porque ya el dardo letal permanece pegado al costado: «haeret lateri lethalis arundo» (Eneida IV, 73). Así sentenciaba también Santillana en su famosa glosa al proverbio, que definía erróneo, «quan lexos d'ojos tan lexos de coraçón», ya citado en el siglo XII por el trovador Arnaut de Mareuil: «Que huehls no vezo cors ne dol» (Dona genser qu'ieu no sai dir, v. 71) ${ }^{27}$. Para Santillana, la ausencia aumenta el deseo («cuanto más vos soy absente, / más vos amo ciertamente / y desseo toda hora», vv. 5-7) y provoca «dolor de vos non mirar» (v. 21), porque el amor permanece «sin compaña de los ojos / mas del leal coraçón» (vv. 9-10). Por esto, en la despedida del poema, el Marqués espera ver a su mujer pronto («çedo vos vean mis ojos / de todo buen coraçón», vv. 23-24). En lo mismo confía Enrique de Aragón («çedo vos vean mis ojos») para que la presencia de la amada pueda servirle de remedio a sus cuitas amorosas («porque çessen mis enojos»). Así se declara también en los últimos versos de la "Pregunta de un caballero a otro, sirviendo entrambos a una dama" (Nájera 1993: 29):

Cómo podré yo curarme 5

d'una llaga tan mortal

que, si quiero remediarme,

hallo en el remedio el mal.

27 Juan Carlos López Nieto (López de Mendoza 2000: 184) dice del refrán que es uno de los «Refranes que diçen las viejas tras el fuego atribuidos al Marqués: “Tan lueñe de ojos, tanto de corazón” (M J. Canellada (ed.) 1980: núm. 677)». 
y en la "Respuesta” (Nájera 1993: 30):
Aunque la llaga es mortal
tiene la causa tal medio
que en el mal está el remedio
si en el remedio está el mal.

La renuncia a escapar y, por consiguiente, la voluntad de afrontar los sufrimientos de amor se expresa en cambio en la traducción de Els cants d'Amor de Ausiàs March (Canto I) por Jorge de Montemayor:
De mil gentes seré reprehendido
porque la vida triste alabo y quiero; mas yo que vi su gloria no he querido huyr d'un mal do tanto bien espero: sin experiencia nadie havrá sabido el bien de que da un querer puro y syncero, y haviéndose desta arte con su dama él mismo se ama a sí en ver que ama (Esteva de Llobet 2014: 377).

Es seguro que negarse a ver a la amada, como afirmaba Varchi (1841: II, 34), «può all'Amor divino e celeste convenire, anzi viepiù che al terrestre ed umano, conciosiacosachè chi ha l'animo elevato, meno resiste a' colpi delle bellezze interne, che non fanno i cupidi e ingordi dei piaceri carnali, a quegli delle bellezze corporee». La imagen del amador atormentado que describía Petrarca, y que sufre penas de herencia cortés, comunica el deseo espiritual de elevarse, de unirse a su amada por medio de un sentimiento que no tiene relación con la posesión física sino con el deseo de llegar al amor de una mujer que encarna todas virtudes y bienes (Wen-Chin Li 2015: 3). Una teoría que parece aflorar en los versos conclusivos de la "Relación del Amor" (vv. 171-175) de Boscán en el Cancionero general de obras nuevas:

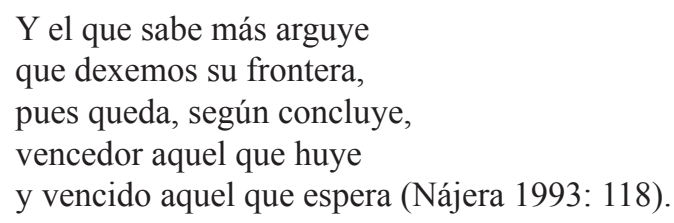

A tenor de lo dicho, ¿podría el deseo de no negarse a Amor aludir al remedio que los poetas cancioneriles invocaban para aliviar las penas de amor? Si así fuera, se trataría de una «ambigüedad como recurso literario»-empleado consciente o inconscientemente- que resulta «no de la falta de información necesaria, sino de la interferencia con una información superflua» (Deyermond 1982: 363-364). De hecho, Cartagena se muestra «consciente de que su decisión no se atiene a la razón, pero aun así, sabe qué debe hacer» (Cartagena 2000: 130), conciencia que el poeta español ya había expresado en otro poema suyo, donde se expresa el deseo de seguir sufriendo, y el remedio incondicional lo representa la misma mujer ${ }^{28}$ :

28 Sobre los remedia amoris de la lírica cortés véase Rodado Ruiz (2000: 102-108). 
A mi mal malgradescido
¿qué remedio
daré, sin vos, que lo sea? (Cartagena 2000: 142, vv. 28-30).

En la esparsa Si no es amor quien me trata, el poeta-amante, que quiere sufrir las pasiones de amor, está expresando su deseo de ser aceptado por la mujer para que él logre alcanzar la gloria, es decir, para que por su dama sea galardonado. Lo que a partir de las teorías de Whinnom (1968-1969 y 1981) sería eufemísticamente alusivo al goce de los placeres sexuales.

\section{Observaciones conclusivas}

El análisis ofrecido propone diferentes lecturas de un soneto del Canzoniere que sirvió de modelo a diversos autores españoles, quienes seguramente no tenían $R v f$ CXXXII como única fuente de inspiración; en los poemas analizados, Cartagena y Boscán parecen extraer del soneto italiano únicamente el tema de los sentimientos en contraste, con algunos reenvíos alusivos al tema de la navegación. En este último caso se trataría de una deuda petrarquesca disfrazada en estas refundiciones de $R v f$ CXXXII, de una de las huellas del escritor italiano reelaborada en un código poético distinto $^{29}$. El intertexto analizado y las elecciones léxicas «ayudan a reconocer en los poetas voces matizadas, no esclavas de un sistema único, de una ética o estética monolíticas», y permiten deducir que las composiciones examinadas en esta sede esconden «una sensibilidad y una inteligencia individuales» (Whetnall 2006: 108) y son muestra de un concepto de imitación «aplicado a conciencia por los creadores» (Micó 2004: 179).

En su lectura del afortunado soneto de Petrarca, ambos poetas españoles dejan traslucir un vínculo con una tradición anterior a la petrarquista, y reconducible en la quintilla de Cartagena al dolce stil novo, y, en la elección de «trata», a la literatura latina. Por lo tanto, la imitación del poeta converso parece al mismo tiempo tomar el ejemplo directo de Petrarca y el de otros poetas italianos a caballo entre los siglos XIII y XIV, que también influyeron en el escritor de Arezzo: serían aquellos modelos italianos no identificados, pero distintos de Petrarca, que Alonso (2001: 145-147) creía que intervinieron en la composición de la esparsa.

En el caso de Boscán, parece, en cambio, evidente un enfoque cancioneril de la lectura del soneto, como confirmaría la elección de tratar -que también podría indicar una voluntad de exploración léxica- y el empleo de temáticas estrictamente tardomedievales, pero sin insistir en el deseo de sufrir el poeta las penas de amor. En efecto, es en la producción lírica en arte menor del barcelonés donde los «figuranti marini, non sempre necessariamente legati al motivo della navigazione amorosa, si presentano in modo non occasionale», mientras que «l'universo lirico - ove domina un sentimento di desiderata sofferenza, proprio dell'amore cortese di radice medievale, ma anche comune matrice della poesia di ispirazione petrarchista - non era del tutto congeniale al poeta barcellonese» (Sarmati 2005: 427, 446).

29 Con estas palabras Francisco Rico (1978: 333) planteaba el problema de identificar el enramado de deudas petrarquescas en la poesía petrarquista española. 
En ambos casos, estamos frente a una adaptación de los contenidos del soneto petrarquesco a la manera castellana, a partir de su legado cancioneril. Se trata de una recíproca impregnación entre dos corrientes poéticas, que ya se manifiesta en la esparsa de Cartagena. Las referencias a fuentes alternativas a $R v f C X X X I I$ y las afinidades entre los dos poemas españoles siempre aparecen en relación con el tema de partida, es decir, con la enunciación semántica y retórica de la concordia discors del yo lírico, tema que resulta predominante y que los poetas deciden desarrollar en detrimento de otros (como el de la tormenta), a los que únicamente remiten algunas elecciones léxicas que esconden las imágenes petrarquescas en un nivel de percepción secundario y localizable solo en la comparación con el soneto original. Por estas razones, la esparsa de Cartagena y el soneto de Boscán entrarían a pleno título dentro de la categoría de los rifacimenti (D'Agostino 2001: 113-114), es decir, de las traducciones «parciales» o «camufladas» (Micó 2004: 198), por esconder elementos textuales de la composición original e interpolar otros ajenos. En efecto, se trataría de un proceso de «adaptación y naturalización» del soneto italiano, cuyo modelo poético se combina con otros en aquella «imitación compuesta» que «fue en la época, y especialmente en el siglo XVI, un modo habitual de creación poética» (Micó 2004: 179).

\section{Referencias bibliográficas}

Alonso, Álvaro (2001): «Garci Sánchez de Badajoz y la poesía italiana», en P. Botta, I. Pérez Pascual, C. Parrilla (eds.), Canzonieri iberici, II, Noia, Toxosoutos, pp. 141-152.

Alonso, Álvaro (2005): «Petrarquismo en octosílabos: del Cancionero de Urrea al de Pedro de Rojas», El canzoniere de Petrarca en Europa: ediciones, comentarios, traducciones y proyección. Cuadernos de Filología Italiana, núm. extr., pp. 235-246.

Antonelli, Roberto (1992): «Rerum vulgarium fragmenta di Francesco Petrarca», en A. Asor Rosa (dir.), Letteratura Italiana Einaudi. Le Opere, vol. I, Turín, Einaudi, pp. 379-471.

Balmas, Enea (1975): «Prime traduzioni dal Canzoniere nel Cinquecento francese», en Traduzione e tradizione europea del Petrarca. Atti del Terzo Convegno sui problemi della traduzione letteraria (Monselice, 9 de junio de 1974), Padua, Antenore, pp 37-54.

Bartomeu Masiá, María José (2007): «Los sonetos y canciones del poeta Francisco Petrarcha de Enrique Garcés. Nota sobre el Canzoniere de Francesco Petrarca en la América del s. XVI», Revista de literatura, 69/138, pp. 449-465.

Boscán, Juan (1971): Liriche scelte, ed. de G. Caravaggi, Turín, Einaudi.

Boscán, Joan (1999): Poesía, ed. de P. Ruiz Pérez, Madrid, Akal.

Brugnolo, Furio / Garribba, Aviva (2006): «Enrique Garcés traductor del Canzoniere (1591). Aspectos lingüísticos, estilísticos y métricos», en M. Lamberti (ed.), Petrarca y el petrarquismo en Europa y América. Actas del Congreso (México, 18-23 de noviembre de 2004), México, UNAM, pp. 289-306.

Canals Piñas, Jorge (1994): «Salomón Usque: una apostilla a la traducción del Canzoniere de Petrarca», Verba Hispanica, 4(1), pp. 159-162.

Canals Piñas, Jorge (2005): «Salomón Usque y la primera traducción castellana del Canzoniere», El canzoniere de Petrarca en Europa: ediciones, comentarios, traducciones y proyección. Cuadernos de Filología Italiana, número extr., pp. 103-114.

Canals Piñas, Jorge (2007a): «Francisco Trenado de Ayllón y el léxico petrarquista», en L. Blini, M.V. Calvi, A. Cancellier (eds.), Linguistica contrastiva tra italiano e lingue iberiche, Madrid, Instituto Cervantes - AISPI, pp. 62-76. 
Canals Piñas, Jorge (2007b): «Tres traductores quinientistas frente al Canzoniere de Petrarca: Usque, Garcés, Trenado de Ayllón», en M. Muñiz Muñiz (ed.), La traduzione della letteratura italiana in Spagna (1300-1939), Florencia, Franco Cesati, pp. 361-372.

Canals Piñas, Jorge (2009): De los sonetos, canciones, mandriales y sextinas del gran poeta y orador Francisco Petrarca, traduzidos de toscano por Salomón Usque (Venecia: 1567), Trento, Università.

Caravaggi, Giovanni (2014): «Esteban Godines de Nájera y Juan Coloma», Revista de poética medieval, 28, pp. 177-187.

Cartagena, Pedro de (2000): Poesía, ed. de A. M. Rodado Ruiz, Cuenca, Ediciones de la Universidad de Castilla-La Mancha /Ediciones de la Universidad de Alcalá.

Cases, Cesare (1975): «Il sonetto in Germania e le prime traduzioni di sonetti petrarcheschi», en Traduzione e tradizione europea del Petrarca. Atti del Terzo Convegno sui problemi della traduzione letteraria (Monselice, 9 de junio de 1974), Padua, Antenore, pp. 65-76.

Cortijo Ocaña, Antonio (2007): «El Siervo libre de amor y Petrarca: a propósito del motivo de la nave», Revista de poética medieval, 18, pp. 133-154.

Crawford, James Pyle Wickersham (1916): «Notes on the sonnets in the Spanish Cancionero general of 1554», Romanic Review, VII, pp. 328-338.

Cruz, Anne J. (1998): Imitación y transformación: el petrarquismo en la poesía de Boscán y Garcilaso, Amsterdam, John Benjamins.

D'Agostino, Alfonso (2001): Traduzione e rifacimento nelle letterature romanze medievali, en M. G. Cammarota, M. V. Molinari (ed.), Testo medievale e traduzione, Bergamo, University Press, pp. 113-125.

Deyermond, Alan (1982): «La ambigüedad en la literatura medieval española», en G. Bellini (ed.), Actas del Séptimo Congreso de la Asociación Internacional de Hispanistas (Venecia, 25-30 de agosto de 1980), Roma, Bulzoni, vol. I, pp. 363-364.

Dutton, Brian (1990-1991): El cancionero del siglo XV, Salamanca, Universidad, vol. V.

Esteva de Llobet, Lola (2014): «Jorge de Montemayor, traductor de Els cants d'amor de Ausiàs March del lemosín al castellano», eHumanista, 28, pp. 369-383.

Facini, Laura (2015): «La costruzione sintattica del sonetto di Juan Boscán», Il confronto letterario, LXIII, pp. 49-74.

Federici, Marco (2016): «Sulla traduzione castigliana di Muoviti, Amore, e vattene a Messere (Decameron, X:7)», Carte romanze, 4(1), pp. 35-60.

Federici, Marco (2018): «Le antiche versionni spagnole di S'amor non è, che dunque è quel ch'io sento? (Rvf CXXXII)», Cahiers d'études italiennes, 27, pp. 1-15.

Forcellini, Egidio (1771): Totius Latinitatis Lexicon, I-IV, Padua.

Foscolo, Ugo (1824): Saggi sopra il Petrarca pubblicati in inglese da Ugo Foscolo e tradotti in italiano, Lugano, Vanelli.

Garribba, Aviva (2003a): «Il petrarchismo in America Latina nel Cinquecento: il caso di Enrique Garcés», Il confronto letterario, 40, pp. 247-261.

Garribba, Aviva (2003b): «La prima traduzione completa del Canzoniere di Petrarca in spagnolo: "Los sonetos y canciones del Petrarcha, que traduzía Henrique Garcés de lengua thoscana en castellana" (Madrid, 1591)», Artifara, 3, <http://www.cisi.unito.it/artifara/ rivista3/testi/petrarca.htm>.

Garribba, Aviva (2005): «Aspectos léxicos de la traducción del Canzoniere por Enrique Garcés (1591)», El canzoniere de Petrarca en Europa: ediciones, comentarios, traducciones y proyección. Cuadernos de Filología Italiana, número extra., pp. 115-132.

Garribba, Aviva (2013): «El compromiso civil cruza las fronteras: la imitación de Italia mia de Enrique Garcés, traductor del Canzoniere», en A. Cassol, D. Crivellari, F. Gherardi, P. 
Taravacci (eds.), Frontiere: soglie e interazioni i linguaggi ispanici nella tradizione e nella contemporaneità. Atti del XXVI Convegno dell'Associazione Ispanisti italiani (Trento, 27-30 de octubre de 2010), Trento, Università, Collana "Labirinti", 152, vol. I, pp. 269-286.

Gerlo, Michael (1994): Poesía cancioneril castellana, Madrid, Akal.

Ibn Hazm, Abdu Muhammad Alî (2017): El collar de la paloma, trad. de E. García Gómez, Barcelona, Red.

Jammes, Robert / Mir, Marie-Thérèse (1993): Glosario de voces anotadas en los 100 primeros volúmenes de Clásicos Castalia, Madrid, Castalia.

Kossoff, A. David (1966): Vocabulario de la obra poética de Fernando de Herrera, Madrid, Real Academia Española.

Krebs Bermúdez, Víctor E. (1995): «Las traducciones de un soneto de Petrarca en el Renacimiento español», en R. Recio (ed.), La traducción en España. Siglos XIV-XVI, León, Universidad de León, pp. 191-220.

Laguna Mariscal, Gabriel (2011): «Travesía de amor», en R. Moreno Soldevilla (ed.), Diccionario de motivos amatorios en la literatura latina (siglos III a.C.-II d.C.), Huelva, Universidad, pp. 424-426.

Lapesa, Rafael (1962 [1967]): «Poesía de cancionero y poesía italianizante», De la Edad Media a nuestros días, Madrid, Gredos, pp. 145-191.

Lefèvre, Matteo (2013): «Boscán ante Petrarca. El proyecto de un cancionero imposible», Studia aurea, VII, pp. 83-108.

López de Mendoza, Íñigo (2000): Antología poética, ed. de J. C. López Nieto, Madrid, Akal. Manero Sorolla, María Pilar (1987): Introducción al estudio del petrarquismo en España, Barcelona, PPU.

Manero Sorolla, María Pilar (1989): «La primera traducción de las Rimas de Petrarca en lengua castellana: Los sonetos, canciones, mandriales y sextinas del gran poeta y orador Francisco Petrarca de Salomon Vsque (Venecia 1567)», en A. Sotelo Vázquez, M.C. Carbonell (eds.), Homenaje al Prof. Antonio Vilanova, Barcelona, Universidad, vol. I, pp. 377-391.

Manero Sorolla, María Pilar (1990): Imágenes petrarquistas en la lírica española del Renacimiento. Repertorio, Barcelona, PPU.

Matos Fernández, Juan (2011) «Masturbación», en R. Moreno Soldevilla (ed.), Diccionario de motivos amatorios en la literatura latina (siglos III a.C.-II d.C.), Huelva, Universidad de Huelva, pp. 265-266.

Melchionda, Mario (1975): «Chaucer, Wyatt e le "contrarietà dell'amoroso stato": Canzoniere CXXXII e CXXXIV nella letteratura inglese», en Traduzione e tradizione europea del Petrarca. Atti del Terzo Convegno sui problemi della traduzione letteraria (Monselice, 9 de junio de 1974), Padua, Antenore, pp. 5-36.

Micó, José María (2004): «La época del Renacimiento y del Barroco», en F. Lafarga, L. Pegenaute (eds.), Historia de la traducción en España, Salamanca, Ambos Mundos, pp. 175-208.

Montero, Juan (2005): «La poesía del Siglo de Oro en sus antologías impresas: el Cancionero general de obras nuevas (Zaragoza, Esteban de Nájera, 1554)», en B. López Bueno (dir.), En torno al canon: aproximaciones y estrategias, Sevilla, Universidad de Sevilla, pp. 413-438.

Nájera, Esteban Godines de (1993): Cancionero general de obras nuevas (Zaragoza, 1554), ed. de C. Clavería, Barcelona, Delstre's.

Pérez González, Ana (2016): «El Castillo del Amor en las artes figurativas bajomedievales», Revista Digital de Iconografía Medieval, VIII/16, pp. 5-30. 
Petrarca, Francesco (1996 [2004]): Canzoniere, ed. de U. Dotti, Roma, Donzelli.

Petrarca, Francesco (2003): Canzoniere, introducción de U. Foscolo, notas de G. Leopardi, ed. de U. Dotti, Milán, Feltrinelli.

Pinto, Raffaele (2016): «Ausiàs March e gli italiani», Quaderns d'Italià, 21, pp. 131-150.

Pirovano, Donato (2012): Poeti del doce stil novo, Roma, Salerno.

Praz, Mario (1935): «Petrarchismo», en Encicolpedia italiana <http://www.treccani.it/enciclopedia/petrarchismo_\%28Enciclopedia-Italiana\%29/>.

Rea, Roberto (2007): «Sul petrarchismo di Juan Boscán. La forma-canzoniere del Libro II dell'edizione del 1543 e il ms. Lastanosa-Gayangos», Studj Romanzi, III, pp. 89-133.

Rico, Francisco (1978): «De Garcilaso y otros petrarquismos», Revue de Littérature Comparée, LII, pp. 325-338.

Rico, Francisco (1987): «A fianco di Garcilaso: poesia italiana e poesia spagnola nel primo Cinquecento», Studi petrarcheschi, 4, pp. 229-236.

Rodado Ruiz, Ana María (2000): "Tristura conmigo va": fundamentos de amor cortés, Cuenca, Ediciones Castilla-La Mancha.

Rojas, Fernando de (1998): La Celestina, ed. de D. Severin, Madrid, Cátedra.

Romà Herèdia, Laura (2014): «L'interés de Gaspar Escolano per la llengua i la literatura medievals i per Ramon Llull, a la Década primera de la historia de Valencia (1610)», SCRIPTA. Revista internacional de literatura $i$ cultura medieval i moderna, 4, pp. 6879.

Rossellini, Aldo (1993): La parola ritrovata: Foscolo, Leopardi, Manzoni, D’Annunzio e la lingua francese, ed. de U. Colombo, B. Martinelli, M. T. Zanola, Milano, Istituto propaganda libraria.

Rubio Tovar, Joaquín (1997): «Algunas características de las traducciones medievales», Revista de Literatura Medieval, IX, pp. 197-243.

Rubio Tovar, Joaquín (2005): «El soneto CXLVIII de Petrarca traducido por Enrique de Villena: ¿original o traducción?», Cuadernos de Filología Italiana, 12, pp. 87-102.

Sarmati, Elisabetta (2009): Naufragi e tempeste d'amore. Storia di una metafora nella Spagna dei Secoli d'Oro, Roma, Carocci.

Sarmati, Elisabetta (2005): «Dalla tempesta alla bonança: variazioni iconografiche all'interno del lessico marino boscaniano», Critica del testo, VIII(1), pp. 427-446.

Socas, Francisco (2011): «Miedo al amor», en R. Moreno Soldevilla (ed.), Diccionario de motivos amatorios en a literatura latina (siglos III a.C.-II d.C.), Huelva, Universidad de Huelva, pp. 272-275.

Tucci, Patrizio (2016): «Traduzioni e imitazioni francesi di un sonetto di Petrarca», en E. Gregori (ed.), «Fedeli, diligenti, chiari e dotti». Traduttori e traduzione nel Rinascimento, Padova, Cleup, pp. 103-125.

Valero Moreno, Juan Miguel (2015): «Guía rápida para el estudio de Petrarca en la península ibérica. Versiones y menciones», Quaderns d'Italià, 20, pp. 191-213.

Valero Moreno, Juan Miguel (2015b): «Petrarca y el Humanismo en la península ibérica», Quaderns d'Italià, 20, pp. 11-35.

Varchi, Benedetto (1841): Lezioni sul Dante e prose varie, ed. de G. Aiazzi y L. Arbib, Florencia, Società editrice delle storie del Nardi e del Varchi.

Wen-Chin, Li (2015): El alma y el amor. Estudio del espiritualismo de Petrarca y su influencia en dos poetas españoles del siglo XVI: Garcilaso de la Vega y Fernando de Herrera. Tesis doctoral inédita. Universidad de Sevilla. 
Whetnall, Jane (2006): «Las transformaciones de Petrarca en cuatro poetas de cancionero: Santillana, Carvajales, Cartagena y Florencia Pinar», Cancionero General, IV, pp. 81108.

Whinnom, Keith (1968-69): «Hacia una interpretación y apreciación de las canciones del Cancionero general», Filología, 13, pp. 361-381.

Whinnom, Keith (1981): La poesía amatoria de la época de los Reyes Católicos, Durham, University of Durham. 